\title{
The necessity of recovering soluble phosphorus from sewage sludge ashes before use in concrete based on concrete setting and workability
}

\author{
N. M. Sigvardsen \& L. M. Ottosen \\ Technical University of Denmark, Denmark
}

\begin{abstract}
By replacing cement with alternative ashes, such as sewage sludge ashes (SSA) from mono-incineration plants, it is possible to reduce $\mathrm{CO}_{2}$-emmision from the production of cement. SSA contains a large amount of phosphate which can be extracted before addition in concrete. The Danish Standard DS/EN 450-1 states an upper limit for total phosphorus in concrete, but it does not account for the solubility. The aim of this study is to determine an upper limit for soluble phosphorus in concrete, thus minimizing the formation of calcium phosphate to an acceptable level. The analysis will be based on the setting and workability. When adding soluble phosphorus salts to a mortar the setting process is extended with no pronounced difference between different soluble phosphorus salts. It is therefore assumed, that the soluble phosphorus (SP) influences the concrete setting. A logarithmic relationship between the increased addition of SP and the initial setting time is seen. By comparison with the limit for an initial setting time established in DS/EN 450-1 it is possible to establish a limit for SP of $0.54 \mathrm{wt} \%$ cement. When studying the workability an objective limit for SP of $0.16 \mathrm{wt} \%$ cement can be established. SSA from the Danish mono-incineration plant at Spildevandscenter Avedøre is examined. At a $\mathrm{pH}$-value of 13 it is possible to replace $55 \%$ and $16 \%$ of the cement, based on the set limits, with SSA from Spildevandscenter Avedøre, before it is necessary to extract SP from SSA before adding to the concrete mixture. Former studies have shown a replacement of up to $20 \%$ of the cement with SSA is feasible regarding compressive strength, and therefore it is necessary to consider the limit for SP of $0.16 \% \mathrm{wt} \%$ cement.

Keywords: soluble phosphorus, sewage sludge ash, concrete setting, concrete workability, setting time, $\mathrm{pH}$ dependent solubility of phosphorus.
\end{abstract}




\section{Introduction}

Production of cement is $4.8 \%$ of the global $\mathrm{CO}_{2}$-emission (Olivier et al. [1]). In order to lower the overall $\mathrm{CO}_{2}$-emmison, decreased use of cement might be an option with high impact. A solution can be to replace a part of the cement in concrete with an alternative puzzolanic material, such as SSA from monoincineration plants. SSA typically contains a high concentration of phosphorus, 5-10\% per unit weight (Ottosen et al. [2]). Phosphorus is an essential element for all life and is not substitutable in the food industry. If the mining of phosphorus isn't reduced or other ways of extracting phosphorus from alternative sources isn't found, the world will be out of phosphorus in 50-100 years (Smil [3]). A solution could be to extract phosphorus from SSA from treatment plants before addition in concrete, and thereby contributing to the decreasing of the vital phosphate reserves. Different techniques are under development for recovery of phosphorus from SSA. The techniques can be grouped in two: thermochemical treatment or chemical extraction, and the methods are reviewed in Donatello and Cheeseman [4].

If SSA is used in the concrete industry as a substitute to cement, it is necessary to study the impact of phosphorus from a concrete technical standpoint. DS/EN 450-1 [5] has set an upper limit for the contents of phosphorus in concrete on $5 \%$ per unit weight, which most of the types of SAA already exceeds. This standard does not take the solubility of the phosphorus in the SSA into account, and thus the formation of calcium phosphorus. By studying the influence of the isolated phosphorus on the concrete setting and workability of fresh concrete it is possible to argue for limit for soluble phosphorus in concrete, and thereby encourage extraction of the phosphorus from SSA before using it in concrete mixes. Assessing the influence of water soluble phosphorus on concrete setting is the aim of the present work.

\subsection{Hydration of the aluminates}

One of the most important aluminates on the concrete setting process is $\mathrm{C}_{3} \mathrm{~A}$ (molecular formula: $3 \mathrm{CaO} \cdot \mathrm{Al}_{2} \mathrm{O}_{3}$ ). The reaction of $\mathrm{C}_{3} \mathrm{~A}$ with water is immediate. Crystalline hydrates are quickly formed and unless the hydration of $\mathrm{C}_{3} \mathrm{~A}$ is slowed down, the concrete cannot be used for most construction applications. To prevent this reaction gypsum is added, and therefore the retardation of $\mathrm{C}_{3} \mathrm{~A}$ by gypsum is one of the important processes in the structural development of concrete (Mehta and Monteiro [6]).

The retardation of $\mathrm{C}_{3} \mathrm{~A}$ proceeds in two steps; first the formation of ettringite (1) flowed by the formation of monosulfate (2).

$$
\begin{gathered}
3 \mathrm{CaO} \cdot \mathrm{Al}_{2} \mathrm{O}_{3}+3\left(\mathrm{CaSO}_{4} \cdot 2 \mathrm{H}_{2} \mathrm{O}\right)+26 \mathrm{H}_{2} \mathrm{O} \rightarrow 3 \mathrm{CaO} \cdot \mathrm{Al}_{2} \mathrm{O}_{3} \cdot 3 \mathrm{CaSO}_{4} \cdot 32 \mathrm{H}_{2} \mathrm{O} \\
2\left(3 \mathrm{CaO} \cdot \mathrm{Al}_{2} \mathrm{O}_{3}\right)+3 \mathrm{CaO} \cdot \mathrm{Al}_{2} \mathrm{O}_{3} \cdot 3 \mathrm{CaSO}_{4} \cdot 32 \mathrm{H}_{2} \mathrm{O}+4 \mathrm{H}_{2} \mathrm{O} \rightarrow \\
3\left(3 \mathrm{CaO} \cdot \mathrm{Al}_{2} \mathrm{O}_{3} \cdot \mathrm{CaSO}_{4} \cdot 12 \mathrm{H}_{2} \mathrm{O}\right)
\end{gathered}
$$


A normal setting extends over 2-4 hours after the addition of water, where the paste becomes less workable between 1-2 hours and begins to solidify within 23 hours. This is the case for a well-balanced addition of $\mathrm{C}_{3} \mathrm{~A}$ and gypsum (Mehta and Monteiro [6]).

\subsubsection{False set}

If the reactivity of $\mathrm{C}_{3} \mathrm{~A}$ is low and the availability of sulphate is high this combination will lead to a rapid formation of large crystals of gypsum with a corresponding loss of consistency. If the mortar contains an adequately low reactivity of $\mathrm{C}_{3} \mathrm{~A}$ and an adequately high availability of sulphate false set occurs, as early as 10 min after the addition of water to the mixture (Mehta and Monteiro [6]).

\section{Materials and methods}

\subsection{Soluble phosphorus salts}

Three types of phosphorus salts with a high solubility were chosen for this study, listed in table 1.

Table 1: $\quad$ Soluble phosphorous salts (Merck Millipore [7]).

\begin{tabular}{|l|c|c|}
\hline & $\begin{array}{c}\text { Solubility in } \\
\text { water [g/l] }\end{array}$ & $\begin{array}{c}\text { Molar mass } \\
{[\mathrm{g} / \mathrm{mol}]}\end{array}$ \\
\hline \multicolumn{3}{|c|}{ Di-sodium hydrogen phosphate dodecahydrate (DSP) } \\
\hline $\mathrm{Na}_{2} \mathrm{HPO}_{4} \cdot 12 \mathrm{H}_{2} \mathrm{O}$ & 218 & 358.14 \\
\hline Tri-sodium phosphate dodecahyrate (TSP) \\
\hline $\mathrm{Na}_{3} \mathrm{PO}_{4} \cdot 12 \mathrm{H}_{2} \mathrm{O}$ & 285 & 380.18 \\
\hline Potassium di-hydrogen phosphate (KDP) \\
\hline $\mathrm{KH}_{2} \mathrm{PO}_{4}$ & 222 & 136.08 \\
\hline
\end{tabular}

The salts are dissolved in dematerialized water before the water is mixed with Basis Cement and sea sand into mortar as described in section '2.2 Mortar mixtures'. When testing the influence of phosphorous on mortar it is assumed that all phosphorus in the salts is soluble.

\subsection{Mortar mixtures}

All mortar mixtures follow the recipe from DS/EN 196-1 [8], except for different kinds or amounts of salts dissolved in dematerialized water before mixture. For the mortar, Basis Cement from Aalborg Portland is used and the sea sand is dried before addition to the mortar. All mixtures are listed in table 2.

The mixing of mortar is conducted cf. DS/EN 196-1 [8]. 
Table 2: Overview of mixtures.

\begin{tabular}{|c|c|c|c|c|}
\hline Mixture & $\begin{array}{c}\text { Basis } \\
\text { Cement } \\
{[\mathrm{g}]}\end{array}$ & $\begin{array}{c}\text { Demineralized } \\
\text { water }[\mathrm{g}]\end{array}$ & $\begin{array}{c}0-4 \mathrm{~mm} \\
\text { sea sand } \\
{[\mathrm{g}]}\end{array}$ & $\begin{array}{c}\text { Phosphorus } \\
\text { compound } \\
{[\mathrm{g}]}\end{array}$ \\
\hline REF & 450.0 & 225.0 & 1350.0 & 0.0 \\
\hline $\mathrm{DSP}(0.73 \mathrm{~g} \mathrm{SP})$ & 450.0 & 225.0 & 1350.0 & 8.41 \\
\hline KDP $(0.73$ g SP) & 450.0 & 225.0 & 1350.0 & 3.19 \\
\hline TSP $(0.73 g$ SP $)$ & 450.0 & 225.0 & 1350.0 & 8.92 \\
\hline $\mathrm{KDP}(0.18 \mathrm{~g} \mathrm{SP})$ & 450.0 & 225.0 & 1350.0 & 0.80 \\
\hline $\mathrm{KDP}(0.36 \mathrm{~g} \mathrm{SP})$ & 450.0 & 225.0 & 1350.0 & 1.60 \\
\hline KDP (1.8g SP) & 450.0 & 225.0 & 1350.0 & 7.91 \\
\hline KDP (2.5g SP) & 450.0 & 225.0 & 1350.0 & 11.05 \\
\hline $\mathrm{KDP}(4.36 \mathrm{~g} \mathrm{SP})$ & 450.0 & 225.0 & 1350.0 & 19.17 \\
\hline KDP (6.54g SP) & 450.0 & 225.0 & 1350.0 & 28.75 \\
\hline
\end{tabular}

\subsection{Concrete setting and workability}

Concrete setting refers to the solidification of the plastic cement paste (Mehta and Monteiro [6]) and is analyzed based on initial and final setting time. Initial and final setting time was measured with a Vicatronic, cf. DS/EN 196-3 [9].

The initial setting time represents the time where the fresh concrete becomes unworkable and concrete placement, compaction and finishing operators becomes difficult beyond this stage (Mehta and Monteiro [6]). Initial setting time is defined as the first time measurement where the needle of the Vicatronic penetrates the specimen up to $0.5 \mathrm{~mm}$ from the bottom of the specimen (DS/EN 196-3 [9]).

Final setting time represents the time where solidification is complete and after which strength begins to develop (Mehta and Monteiro [6]). Final setting time is defined as the first time measurement where the needle of the Vicatronic sinks $6 \pm 3 \mathrm{~mm}$ into the mortar sample (DS/EN 196-3 [9]).

Workability is assessed objectively by comparing the reference mixture with a mortar mixture added salts in a wet condition and the surface of the set specimens after setting.

\subsection{SSA for the experimental work and $\mathrm{pH}$ dependent solubility of phosphorus}

The SP concentration in alkaline solutions was evaluated for an SSA from the Danish mono-incineration plant at Spildevandscenter Avedøre. The sludge incinerated at the plant originated from municipal wastewater treatment. Iron was used in the waste water facility to precipitate phosphorus, and the sewage sludge was incinerated in a fluidized bed combustor about $806^{\circ} \mathrm{C}$.

Extraction of phosphorus from SSA is determined by examination of SSA in alkali solutions; $0.01 \mathrm{M} \mathrm{NaOH}, 0.05 \mathrm{M} \mathrm{NaOH}, 0.1 \mathrm{M} \mathrm{NaOH}, 0.5 \mathrm{M} \mathrm{NaOH}$ and 
$1.0 \mathrm{M} \mathrm{NaOH}$. The pH-values of the solutions are measured and the concentrations of phosphorus in the solutions are measured by ICP. The SSA is crushed before conducting the experiment, since former studies have shown that crushing the ashes before adding to a mortar mixture gives a more puzzolanic effect in the same range as cement (Donatello et al. [10]).

\section{Results and discussion}

\subsection{Soluble phosphorus salts in fresh mortar}

To be able to determine whether it is the SP or another component in the soluble phosphorus salt which influences the initial and final setting time, mixtures with $0.73 \mathrm{~g}$ SP were tested with DSP, KDP and TSP. Furthermore KDP has the highest solubility in water, and is therefore used to test for a limit for phosphate in mortar based on setting and workability. Prior this study Wittendorff [11] has measured the initial and final setting time of a mixture with an addition of $2.7 \mathrm{~g}$ ADP corresponding to $0.73 \mathrm{~g} \mathrm{SP}$, and this result will be included in this paper.

Figure 1 shows the setting process of a reference specimen, three specimens added the three chosen salts corresponding to $0.73 \mathrm{~g}$ SP and ADP corresponding to $0.73 \mathrm{~g}$ SP conducted by Wittendorff [11].

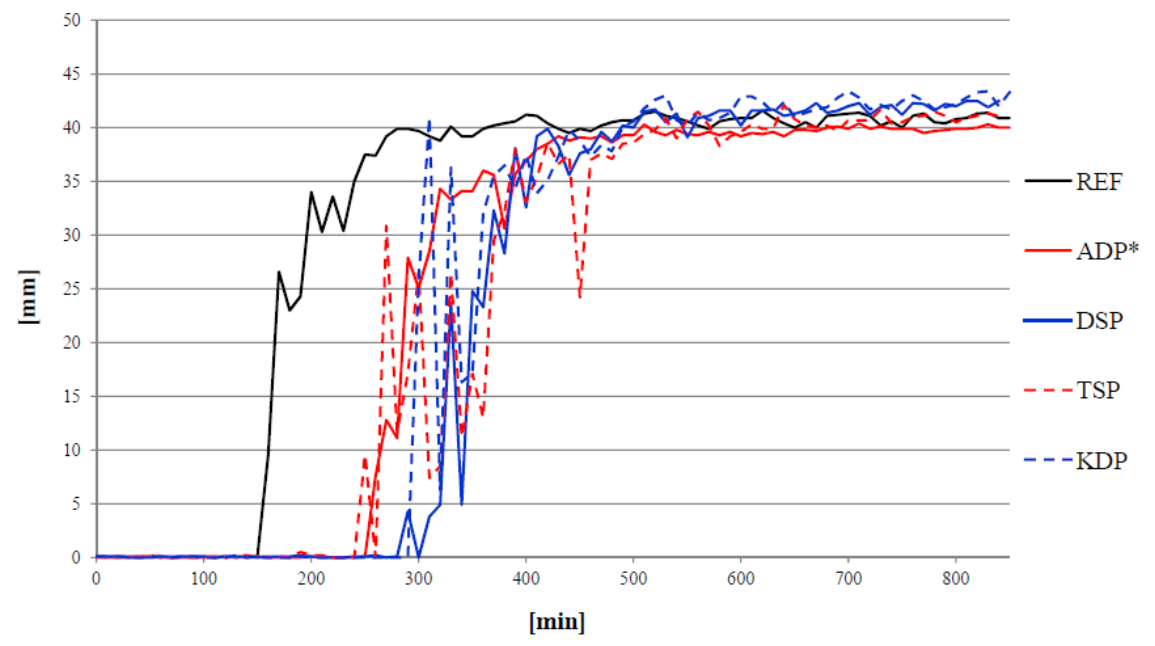

Figure 1: $\quad$ Setting process for specimens added 0.73g SP (*from Wittendorff [11]).

For all specimens added $0.73 \mathrm{~g} \mathrm{SP}$ is seen a retardation of both initial and finial sets and the course is more uneven compared to the reference sample. All figures containing salts sets later than the reference specimen.

Table 3 shows the initial and finial setting time for the specimens added the four types of salts and their respective deviation from the reference specimen. 
Table 3: Setting time for specimens added $0.73 \mathrm{~g}$ phosphorus (*from Wittendorff [11]).

\begin{tabular}{|l|c|c|c|c|c|}
\hline & $\begin{array}{c}\text { Initial } \\
\text { setting } \\
\text { time } \\
{[\mathbf{m i n}]}\end{array}$ & $\begin{array}{c}\text { Deviation } \\
\text { from REF } \\
{[\%]}\end{array}$ & $\begin{array}{c}\text { Final } \\
\text { setting } \\
\text { time [min] }\end{array}$ & $\begin{array}{c}\text { Initial to } \\
\text { final setting } \\
\text { time [min] }\end{array}$ & $\begin{array}{c}\text { Deviation } \\
\text { from REF } \\
{[\%]}\end{array}$ \\
\hline REF & 160 & - & 410 & 250 & - \\
\hline ADP* & 260 & 63 & 540 & 280 & 12 \\
\hline DSP & 330 & 106 & 670 & 340 & 36 \\
\hline TSP & 250 & 56 & 560 & 310 & 24 \\
\hline KDP & 300 & 88 & 600 & 300 & 20 \\
\hline
\end{tabular}

The initial and final setting time for the reference specimen corresponds well with normal-setting given by Mehta and Monteiro [6].

$\mathrm{DS} / \mathrm{EN}$ 450-1 [5] is used as a basis for determination of a limit of SP in mortar. DS/EN 450-1 [5] is a standard for fly ash, but since none has been drafted for SSA yet DS/EN 450-1 [5] is used instead. DS/EN 450-1 [5] establishes requirements for initial setting time, when fly ash is added to the mixture, that must not exceed 2.25 times the initial setting time for the reference sample. The addition of soluble phosphorus salts prolongs the initial setting time, but all measurements comply with the limit for initial setting time according to DS/EN 450-1 [5]. The measured time from initial to final setting time is likewise prolonged though not as severe. These results was expected, as phosphoric acids and their salts mixed with mortar results in retardation of initial and final set among other things (Kurdowski [12]).

Cement contains elements like calcium oxides $(\sim 63 \%)$, which is a phosphorus binding element (Egemose et al. [13]). Based on the obtained results, and know theory, the following hypothesis can be drawn up. By adding SP to the mortar mixture, SP reacts with the calcium in $\mathrm{C}_{3} \mathrm{~A}$ and gypsum, forming calcium phosphates and releasing sulfate in the mortar. This causes a prolonging of the structural development and thus the setting time. Furthermore crystallization of gypsum needles starts to form in the pores which cause loss of consistency and finally flash set.

\subsection{Limit for soluble phosphorus in fresh mortar cf. requirements from DS/EN 450-1 [5]}

From figure 2 it is seen that the more SP is added, the longer it takes for the specimen to reach initial and final setting time, except for the highest concentration, where the setting is much faster. This is supported by table 4 .

From table 4, the initial setting time is seen to be delayed the more SP is present, till a fairly large amount of SP is present. Moreover, it is seen that the initial setting does not comply with the limit for initial stetting time according to DS/EN 450-1 [5] for the addition of 4.36g and 6.54g SP, which is below the saturated limit. 


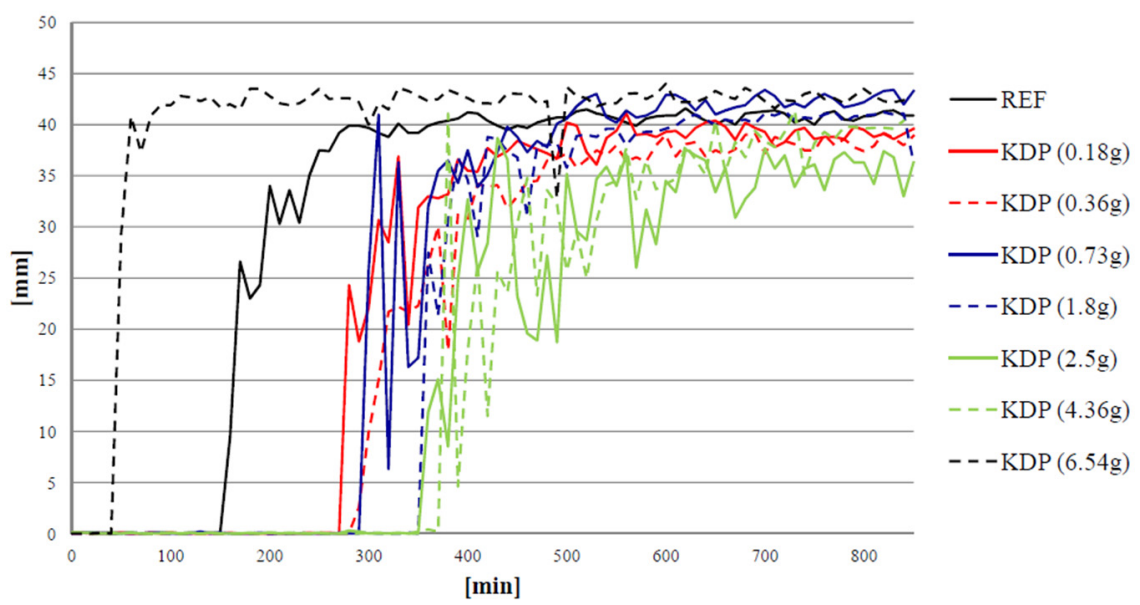

Figure 2: $\quad$ Setting process for specimens added different amounts of SP.

Table 4: $\quad$ Stetting time for specimens added KDP equivalent to $0.18 \mathrm{~g}, 0.36 \mathrm{~g}$, $0.73 \mathrm{~g}, 1.80 \mathrm{~g}, 2.50 \mathrm{~g}, 4.36 \mathrm{~g}$ and $6.54 \mathrm{~g} \mathrm{SP}$.

\begin{tabular}{|l|c|c|c|c|c|}
\hline & $\begin{array}{c}\text { Initial } \\
\text { setting } \\
\text { time [min] }\end{array}$ & $\begin{array}{c}\text { Deviation } \\
\text { from } \\
\text { REF [\%] }\end{array}$ & $\begin{array}{c}\text { Final } \\
\text { setting } \\
\text { time [min] }\end{array}$ & $\begin{array}{c}\text { Deviation } \\
\text { from } \\
\text { REF [\%] }\end{array}$ & $\begin{array}{c}\text { Initial to } \\
\text { final setting } \\
\text { time [min] }\end{array}$ \\
\hline REF & 160 & - & 410 & - & 250 \\
\hline $0.18 g$ SP & 280 & 75 & 500 & 22 & 220 \\
\hline 0.36 g SP & 300 & 87.5 & 550 & 34.1 & 250 \\
\hline 0.73 g SP & 300 & 87.5 & 600 & 46.3 & 300 \\
\hline 1.80 g SP & 360 & 125 & 610 & 48.8 & 250 \\
\hline 2.50 g SP & 360 & 125 & 620 & 51.2 & 260 \\
\hline 4.36 g SP & 380 & 137.5 & 690 & 68.3 & 310 \\
\hline $6.54 \mathrm{~g} \mathrm{SP}$ & 50 & -68.75 & 190 & -53.6 & 140 \\
\hline
\end{tabular}

When adding larger and larger amounts of SP to the mortar more and more SP reacts with the calcium prolonging the structural development and setting time and more and more crystallized gypsum is formed. When adding a fairly large amount of KDP (6.54g) the mortar performs a false set, hence the short initial and final setting time.

Figure 3 shows the correlation between the initial setting time and the added amount of SP to the specimens, with the exception of the specimen added $6.54 \mathrm{~g}$ SP. By using a logarithmic trend line a limit of $2.45 \mathrm{~g}$ SP is read for an initial setting time 2.25 times the initial setting time of the reference specimen cf. DS/EN 450-1 [5]. This corresponds to a limit for SP of $0.54 \mathrm{wt} \%$ cement. From figure 3 it is seen that the limit of 2.25 times the initial setting time of the 
reference specimen already is reached with $1.8 \mathrm{~g}$ SP. It is therefore possible to establish an interval of $[1.8 \mathrm{~g} ; 2.45 \mathrm{~g}] \mathrm{SP}$ until further studies has shown a more clear trend line, which further may account for the specimen with no or very small amounts of SP. Calculations in this work will proceed with the limit for SP of $0.54 \mathrm{wt} \%$ cement.

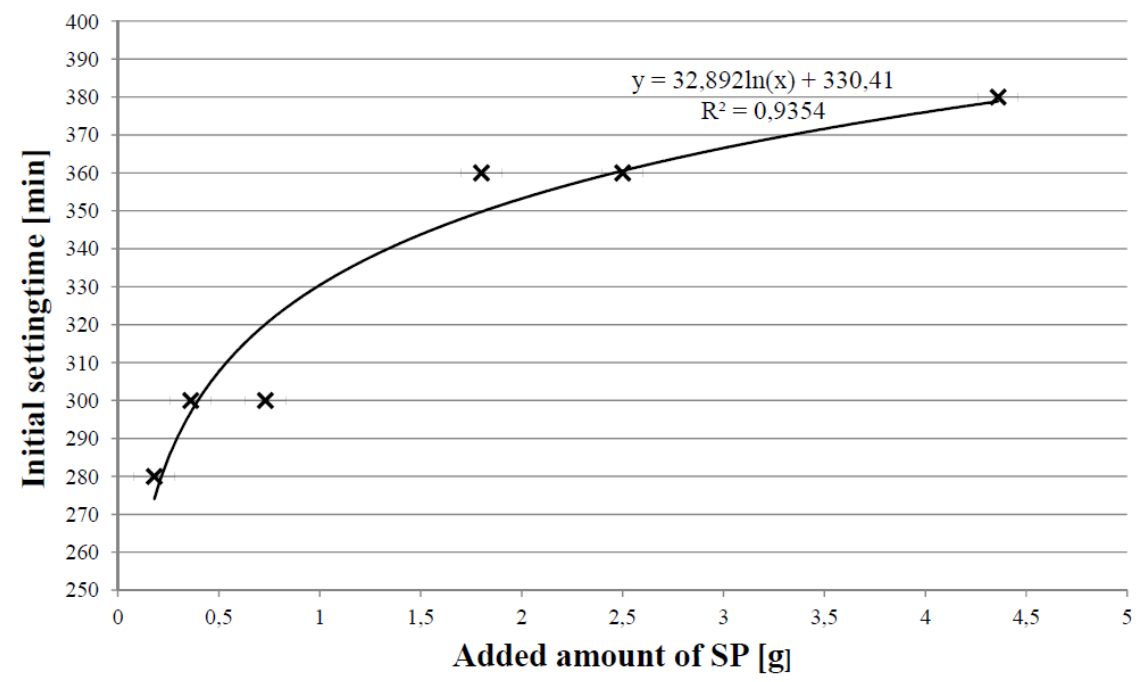

Figure 3: Correlation between initial setting time and added amount of SP.

\subsection{Limit for soluble phosphorus in fresh mortar cf. workability}

When mixing the fresh mortar with different amount of SP the consistency and thus the workability changes remarkably. Figure 4 shows a set specimen added $1.8 \mathrm{~g}$ SP. It is clearly seen how the specimen contains large holes and has an uneven surface, which makes the specimen extremely porous and gives the specimen a poor compressive strength. The fresh mortar was dry and had a poor workability. The more SP is added the more this condition worsened.

This again supports the hypothesis of the crystallization of gypsum in the mortar when calcium and phosphate reacts and sulfate is released, leading to the poor consistency of the mortar. When adding $6.54 \mathrm{~g}$ SP the mortar becomes completely unworkable.

On the basis of an objective comparisons between the reference specimen and the specimens added SP, a limit with respect to the workability can be determined to $0.73 \mathrm{~g} \mathrm{SP}$, corresponding to SP of $0.16 \mathrm{wt} \%$ cement. 


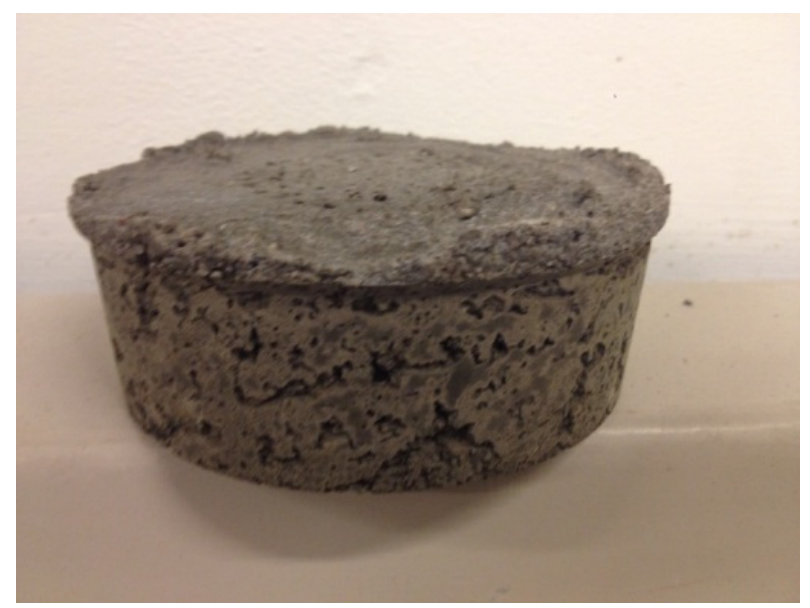

Figure 4: $\quad$ Set specimen added 1.8g SP.

\subsection{The $\mathrm{pH}$ dependence of phosphate desorption in comparison to the established limits}

For comparing the established limits of SP in mortar with the addition of SSA to mortar, it is necessary to amount of SP in SSA at alkaline pH-values. Figure 5 shows desorption of phosphorus from the experimental SSA. The total concentration of phosphorus in the experimental SSA was $97 \mathrm{~g} / \mathrm{kg}$ (Wittendorff [11]).

From figure 5 it is seen that the solubility of the phosphate in the experimental SSA is highly dependent on the $\mathrm{pH}$-value to which it is exposed. This is in accordance to previous findings by Stark et al. [14].

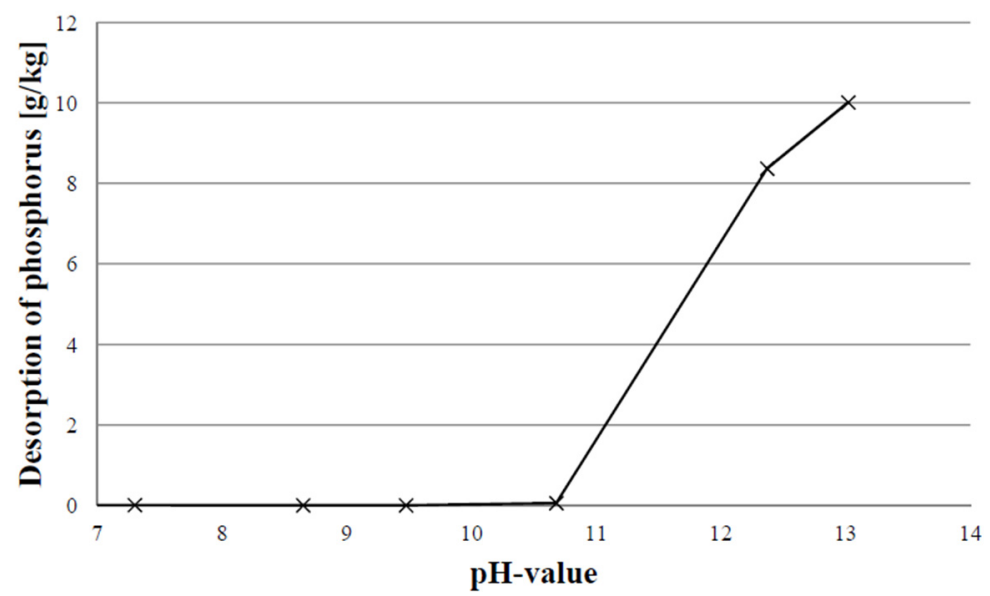

Figure 5: Correlation between desorption of phosphorus and $\mathrm{pH}$-value. 
Table 5 shows how much cement can be replaced the experimental SSA in relation to the establish limits for SP of 0.54 and $0.16 \mathrm{wt} \%$ cement (the conditions found in section ' 3.2 Limit for soluble phosphorus in fresh mortar cf. requirements from DS/EN 450-1 [5]' and '3.3 Limit for soluble phosphorus in fresh mortar cf. workability'). The cement replacement is calculated on basis of the receipt described in section '2.2 Mortar mixtures' and formulae (3) and (4).

$$
\begin{aligned}
& \text { Limit for SP }[\mathrm{g}]=\frac{\text { Calculated limit }[\mathrm{g}]}{\text { Amount of SP at the given } \mathrm{pH}-\text { value }[\mathrm{g} / \mathrm{kg}]} \cdot 1000 \\
& \text { Cement replacement }[\%]=\frac{\text { Limit for } \mathrm{SP}[\mathrm{g}]}{\text { Amout of Basis Cement added }[\mathrm{g}]} \cdot 100
\end{aligned}
$$

Table 5: Replacement of cement with SSA (*no restrictions with regards to SP).

\begin{tabular}{|l|c|c|c|c|c|}
\hline Solution & $\begin{array}{c}\mathbf{p H}- \\
\text { value }\end{array}$ & $\begin{array}{c}\text { Limit of SP } \\
\text { of } \mathbf{0 . 5 4 \%} \text { [g] }\end{array}$ & $\begin{array}{c}\text { Cement } \\
\text { replacement } \\
{[\%]}\end{array}$ & $\begin{array}{c}\text { Limit of SP } \\
\text { of } \mathbf{0 . 1 6 \%} \text { [g] }\end{array}$ & $\begin{array}{c}\text { Cement } \\
\text { replacement } \\
{[\%]}\end{array}$ \\
\hline $\begin{array}{l}\text { Demineralized } \\
\text { Water }\end{array}$ & 7.3 & 352000 & $100^{*}$ & 105000 & $100^{*}$ \\
\hline $0.01 \mathrm{M} \mathrm{NaOH}$ & 8.7 & 0 & 0 & 0 & 0 \\
\hline $0.05 \mathrm{M} \mathrm{NaOH}$ & 9.5 & 0 & 0 & 0 & 0 \\
\hline $0.1 \mathrm{M} \mathrm{NaOH}$ & 10.9 & 43800 & $100^{*}$ & 13100 & $100^{*}$ \\
\hline $0.5 \mathrm{M} \mathrm{NaOH}$ & 12.4 & 293 & 65.1 & 87.2 & 19.4 \\
\hline $1.0 \mathrm{M} \mathrm{NaOH}$ & 13.0 & 245 & 54.4 & 72.9 & 16.2 \\
\hline
\end{tabular}

Depending on the concentration of $\mathrm{Na}^{+}, \mathrm{K}^{+}$and $\mathrm{OH}^{-}$the $\mathrm{pH}$ value of cement ranges from 12.5 to 13.5 (Mehta and Monteiro [6]), and therefore the results for solution with $1.0 \mathrm{M} \mathrm{NaOH}$ are most interesting.

For the actual SSA with a phosphorus concentration of $97 \mathrm{~g} / \mathrm{kg}$ it is possible to replace $54.4 \%$ and $16.2 \%$ before the established limits for SP of 0.54 and $0.16 \mathrm{wt} \%$ cement respectively is exceed. It is thus necessary to extract SP from the SSA. If the phosphate concentration for SSA is lowered to $50 \mathrm{~g} / \mathrm{kg}$ which is required by DS/EN 450-1 [5], it would be possible to replace approximate the double amount of cement.

A replacement of up to $20 \%$ of the cement with SSA has proven feasible regarding compressive strength in former studies (Ottosen et al. [15]), and this makes the limit for SP of $0.16 \% \mathrm{wt} \%$ cement interesting.

\section{Conclusion}

When adding soluble phosphorus salts to a mortar the initial and final setting time is retarded, regardless the salt tested. When adding different amounts of dissolved phosphorus to the mortar the initial and final setting time is retarded 
with increasing addition, until a certain amount where the mortar performs a false set.

A limit for SP of $0.54 \mathrm{wt} \%$ cement can be establish based on the measurements of initial and final setting time in conjunction with DS/EN 450-1 [5] and a limit for SP of $0.16 \mathrm{wt} \%$ cement can be established based on objective assessment of the workability of the fresh mortar.

$\mathrm{SP}$ in the SSA is depending on the $\mathrm{pH}$ value the SSA is subjected to. The SP has a high desorption at $\mathrm{pH} 13.0$, which is the range within the $\mathrm{pH}$ of cement lays. When comprising the established limits with the desorption of SP it is seen that a $55 \%$ and $16 \%$ cement replacement respectively can be conducted before it is necessary to extract SP from the SSA.

Former studies have shown that up to a $20 \%$ cement replacement is feasible regarding compressive strength, and therefore it is necessary to take the established limit for SP of $0.16 \mathrm{wt} \%$ cement into consideration, and consider the necessity of extracting SP before adding SSA to a mortar or concrete mixture.

\section{Acknowledgements}

Laboratory coordinator Ebba C. Schnell and concrete technician Per Leth have been very helpful during the laboratory and concrete laboratory work respectively. We acknowledge Rikke Klavstrup Wittendorff [11] for her prior work with SSA from the Danish mono-incineration plant at Spildevandscenter Avedøre and phosphorus in mortar and her results for initial and final setting time for mortar added $2.7 \mathrm{~g}$ ADP $(0.73 \mathrm{~g}$ SP) and phosphorus content of SSA from the Danish mono-incineration plant at Spildevandscenter Avedøre, which was used in this paper.

\section{References}

[1] Olivier, J. G., Janssens-Maenhout, G., Muntean, M. and Peters, J. A., Trends in global CO2 emissions: 2014 Report. Hauge: Netherlands Environmental Assessment Agency, p. 12, 2014.

[2] Ottosen, L. M., Kirkelund, G. M. and Jensen, P. E., Udvinding af fosfor fra slamaske med elektrokemiskteknik. Denmark: Miljøstyrelsen (In Danish), p. 6, 2015.

[3] Smil, V., Phosphorus in the environment: Natural flows and human interferences. Annual Review of Energy and the Environment, 25, pp. 53$88,2000$.

[4] Donatello, S. and Cheeseman, C., Recycling and recovery routes for incinerated sewage sludge ash (ISSA): A review. Waste Management, 33(11), pp. 2328-2340, 2013.

[5] Danish Standard Euronorm (DS EN) 450, Fly ash for concrete - Part 1: Definition, specifications and conformity criteria. 2012.

[6] Mehta, L. K. and Monteiro, P. J. M., Concrete - Microstructure, properties and materials, fourth edition, McGraw-Hill Education. 2014. 
[7] Merck Millipore: a leading supplier to the global Life Science industry, www:merckmillipore: $\mathrm{com}=\mathrm{DK}=\mathrm{en} .2015$.

[8] Danish Standard Euronorm (DS EN) 196, Methods of testing cement Part 1: Determination of strength. 2005.

[9] Danish Standard Euronorm (DS EN) 196, Methods of testing cement Part 3: Determination of setting times and soundness. 2009.

[10] Donatello, S., Freeman-Pask, A., Tyrer, M., and Cheeseman, C., Effect of milling and acid washing on the pozzolanic activity of incinerator sewage sludge ash. Cement Concrete Comp, 32(1), pp. 54-61, 2010.

[11] Wittendorff, R. K., Anvendelse af alternativ aske i beton - bearbejdelighed og hærdeforløb. Bachelor's thesis, Technical University of Denmark (In Danish). 2014.

[12] Kurdowski, W., Cement and Concrete Chemistry, Springer Netherlands: Dordrecht, p. 236, 2014.

[13] Egemose, S., Sønderup, M. J., Beinthin, M. V., Reitzel, K., Mann, C. C. H. \& Flindt, M. R., Crushed concrete as a phosphate binding material: A potential new management tool. Journal of Environmental Quality, 41(3), pp. 647-653, 2012.

[14] Stark, K., Plaza, E., and Hultman, B., Phosphorus release from ash, dried sludge and sludge residue from supercritical water oxidation by acid or base. Chemosphere, 62(5), pp. 827-832, 2006.

[15] Ottosen, L. M., Jensen, P., Golterman, P., and Kirkelund, G., Sewage sludge ash as cement replacement after simple pretreatment. Proceedings Sardinia 2013, Fourteenth International Waste Management and Landfill Symposium. 2013. 